\title{
Imaginace genư a hranice etnických identifikací
}

\author{
Imaging Genes and the Borderlines of Ethnic Identifications
}

\author{
Eva Šlesingerová
}

\begin{abstract}
Taking advantage of critical cultural theory, this text examines the narrative concerning the complementarity of sameness and difference in the production of knowledge within interpretations of a National Geographic article. The representations of "sameness" and "difference" presented in this article refer to the cultural imagination of genomic and DNA research in connection with notions of nationality and ethnicity. The following text examines the consequences of using words and images connected with concepts of "origin" or the imagination of the body in relation to the construction of core-groups or core solidarity of specific communities.
\end{abstract}

KEY WORDS biopolitics, body, ethnicity, genomic research, nature/culture

\section{Úvod}

Dlouho před svítáním vyplouvají každý den rybáři ze Súru, starověkého Tyru, se svými loděmi stejně, jako to činili od nepaměti jejich předkové. Kolem deváté hodiny dopoledne se vracejí do př́istavu a po práci odpočívají při kávě a kartách v kavárně na pobřeží. Právě tam je Spencer Wells, badatel pracující pro National Geographic, a jeho kolega Pierre Zallúa, genetik z bejrútské Americké univerzity, požádali o účast v rozsáhlém výzkumném projektu. Cílem je zjistit, zda tito rybáři jsou potomky Féničanů $[. .$.$] . Vědci by mohli nalézt odpověd' v dědičných genetických modelech chromozomů Y,$ pokud rybáři přistoupí na to, že věnují vzorky své krve. [...] „Většina lidí se zajímá o svou rodinnou historii,“ “ŕíá Wells. „A fascinuje je myšlenka, že mají ve své krvi tajemství poutající je nejen k jejich prarodičům, ale i k lidem, s nimiž se nikdy nesetkali.“

(R. Gore, „Kdo byli Féničané“, $N G$, ř́ijen 2004: 35)

Čtenář časopisu National Geographic, který se probírá výše zmíněnými řádky, se může či nemusí v údivu pozastavit nad možnostmi současné vědy. Mưže či nemusí se zájmem číst o tom, jakým detailním a sofistikovaným zpơsobem lze zjistit a popsat historii určité etnické skupiny. Údiv či zájem, který stál na počátku mého přemýšlení o tomto typu textů, je ale jiné povahy. To, co se mi jeví jako fascinující impuls pro hlubší analýzu, je předpoklad samozřejmosti nároku na spojení analýzy DNA na jedné straně a etnické identifikace či původu té které sociální skupiny na straně druhé. ${ }^{1} \mathrm{~K}$ tomuto typu výpovědi totiž přistupuji jako ke kulturnímu textu a analyzuji

Sociální studia. Fakulta sociálních studií Masarykovy univerzity v Brně, 2/2005. S. 115-128. ISSN 1214-813X. Tato studie vznikla s podporou Ministerstva školství, mládeže a tělovýchovy - výzkumný záměr „Reprodukce a integrace společnosti" (MSM0021622408). 
ho pomocí nástrojü, které mi nabízejí sociální vědy. Prostřednictvím mého pohledu se tak stanou problematickými právě normalita a banálnost textů vypovídajících o možnostech analýzy genomu, tzn. genetického zmapování tělesnosti, a její spojení s etnickou př́slušností.

Vzhledem $\mathrm{k}$ této mé čtenářské a interpretační pozici mě tak v následujícím textu zajímají hlavně tyto otázky: Jestliže jsou rybáři ze Súru prostřednictvím analýzy genů v proudu dějin přiřazeni ke svým prarodičům, jak je potom tímto symbolickým aktem spoluvytvářena představa o jejich etnické přináležitosti, o jejich původu? Podporují výše zmíněné populární reprezentace genetického výzkumu a analýzy lidské DNA vytváření narativ o etnickém původu? A, jak předchozí věty deklarují, lze k tělu přistoupit jako k mapě či ke klíči otevírajícímu tajemství historie určitého etnika?

Právě sociální vědy nám umožní nahlédnout, jak tyto populární reprezentace odkazující $\mathrm{k}$ „přirozenosti dědictví předkư“ a zároveň $\mathrm{k}$ analýze DNA, spolupůsobí při ustavování vědění o tom, co nazýváme jádrem nacionalizované či etnicizované skupiny (viz Alexander 2003), a jak jsou tímto způsobem konstruovány symbolické hranice solidarity, kterou sdílí jeho členové. Proces vyjednávání hranic mezi přijetím či neprrijetím do core-group se kromě občanských pout a závazků vyznačuje také emocionální solidaritou ke skupině a loajalitou k primordiálním charakteristikám, jimiž jsou například jazyk, akcent, náboženství, př́slušnost k tzv. „rase“, idea prŕbuzenství apod. Právě z hlediska takto definované představy o homogenitě centra národní či etnické skupiny se stává důležitou i analýza sociálních konsekvencí kulturní reprezentace „těla národa“" a odkazy k jeho genofondu. ${ }^{2}$

Následující text se tak snaží načrtnout možné interpretace toho, jak se prostřednictvím kulturní reprezentace tělesnosti, zahrnující i analýzu DNA, může zobrazovat přináležitost k určité etnicky definované komunitě. Konkrétním př́kladem, kterým se zde zabývám, jsou spojení výpovědí o tělech, která se popisují skrze genetický kód, a zároveň výpovědí odkazujících k sebedefinici etnické core-group, jež vytváŕí potenciál i pro identifikaci „těch druhých“, těch, kteří stojí za hranicemi sdílené solidarity.

Ptám se tedy, jak funguje tělesnost a jedna z kategorií života, genom, jako objekt par excellence při utváření symbolických hranic mezi prírodou a kulturou. V tomto kontextu si všímám toho, jak jsou prostřednictvím vyjednávání hranic očištovány prahy mezi etnicizovanými core-group a out-group, „námi““ a „ostatními“", to znamená, jak je solidarita k určitému společenství strukturovaná kolem odkazů na přirozenost ideje původu, předků a kulturalizaci tělesného kódu či mýtu společné krve. Mou snahou je přitom upozornit na procesy reprezentace, které určují, kdy se co prriřazuje sfére prírody či naopak sfére kultury, a jakou roli v tomto procesu hraje diskurs populární reprezentace vědecké analýzy těla a jeho genomu. Odkazy na krev, stejně tak jako na analýzu DNA, jsou zde přitom kulturními fenomény stejně tak jako jsou zmínky o původu a o tajemstvích předků součástmi sféry přirozenosti světa konkrétní etnicizované komunity.

\section{Imaginace DNA, krev předků a etnicita}

Výzkum lidské DNA je kromě výzkumných zpráv biologů či genetiků, tedy diskursivních výpovědí z oblasti prírodních věd, také součástí veřejných promluv, v prípadě mé analýzy promluv popularizačních. Zde je třeba zdůraznit diskursivní pozici, z jaké texty a vizualizace v $\mathrm{Na}$ tional Geographic popisuji, a také samozřejmě typ kontextu těchto ilustrativních výpovědí. 
Popularizační diskurs, kterého je National Geographic součástí, je sociálním procesem, jenž sestává z řady diskursivně-sémiotických praktik a zahrnuje mnoho typů médií, která komunikují nejen laické verze vědeckého vědění, ale také přispívají $\mathrm{k}$ definici pozice vědců na veřejnosti. Popularizace není charakterizována pouze textuální strategií, ale je důležité si všimnout i kontextu výpovědi - tzn. účastníků, jejich rolí (vědci, specializovaní žurnalisté, laici, laické či expertní publikum), jejich cílů, víry, forem vědění, stejně tak jako relevance tohoto vědění v každodenním životě lidí. Popularizace obsahuje nejen reformulaci, ale také částečně rekontextualizaci vědeckého vědění a diskursu, který je původně produkován ve zvláštních kontextech, ke kterým má laické publikum omezený př́stup. To znamená, že diskurs popularizace se vždy musí adaptovat na přiměřené podmínky a ostatní omezení médií a komunikativních událostí, denního tisku, specializovaných magazínů. Masová média ale nejsou pasivními prostředníky vědecké informace, naopak aktivně podporuji produkci nového, obecného věděni a mínění o vědě a vědcích - včetně informací a pohledů, které nepocházejí z vědeckých zdrojů (Calsamiglia a van Dijk 2004).

Typ diskursivního narativa, který zde ilustruje text o genetické identifikaci potomků starověkých Féničanů, je specifický jak jistým způsobem vizualizace tělesných charakteristik lidí, které popisuje (viz obrázek 1. a 2.), tak také textuálními odkazy k tělu jako zdroji kulturní informace. Kontextem tohoto typu výpovědí je časopis National Geographic, který můžeme charakterizovat právě jako populárně-naučný magazín, a tedy jako médium umožňující ilustraci výše zmíněného vědecky popularizačního diskursu. Jedním z mnoha zásadních témat tohoto periodika je zobrazování a popis a konstrukce jak toho, co patří do sféry příro$d y$, rostlin, živočichů, tak i toho, co odkazuje k rozmanitosti kultur, k různorodosti globální lidské populace. Různosti, která je nicméně prezentována jako pririrozená ve své skupinové odlišnosti a manifestovaném původu, což znamená, že konkrétní lidé jsou zde chápáni jako reprezentanti homogenních, typizovaných kategorií, například Féničanů, Libanonců, Čangů, sdílejících primordiální charakteristiky stejné krve, čistoty kultury, její autenticity apod. - tak jak to dokládají následující ilustrace:

Byron Billie a Jojo Dakota Osceola jsou oba čistokrevní Seminolové.

(J. Bruchac, „Indiánské obrozeni““, $N G$, říjen 2004: 104)

Toto je silná karpatská společnost v čisté podobě, jaká musela být i tehdy, když tudy projížděli Attila a Árpád v čele jízdních hord.

(F. Viviant, „Písně Čangů“, $N G$, červen 2005: 114)

János Attila Jánó se otevřeně hlásí ke svým kořenům, když na koni projíždí zemí, kde se jeho předkové usadili před nějakými osmi sty lety. Zda tito praotcové byli Hunové (jak naznačuje jeho jméno), Mad’aři nebo Rumuni, zůstává nejasné. Mad’arsko i Rumunsko považují Čengy za své, což je mezi oběma zeměmi zdrojem napětí.

(F. Viviant, „Písně Čangü“, $N G$, červen 2005: 105)

Vrat'me se opět k textu o fénické DNA z National Geographic. Sféra jistoty, kterou zde produkují popularizační výpovědi o dědičnosti či DNA, legitimuje ustavení sociálních vzta- 
hů v prostoru a čase jako nezpochybnitelné a nezpochybňované sady argumentů v prostředí vyjednávání podoby sociálních identit.

Vaše krev osahuje DNA, která připomíná učebnici dějin,“ odpovídá Wells. „V dlouhém staletí přicházelo do Byblosu mnoho různých národů a vaše krev nese stopy jejich DNA. Řekne nám to něco o vašich př́buzenských vztazích tisíce let do minulosti.

(R. Gore, „Kdo byli Féničané“, $N G$, říjen 2004: 37)

Jak můžeme na této ukázce ilustrovat, do těl je vkládáno sociálno, a naopak, sociálno je utvářeno pomocí jistých představ těl. Nenabývají však tyto strategie podob rasizace či etnicizace? Vzrůstající množství výzkumů genetické informace financovaných státem a průmyslovými organizacemi, jako je např́iklad v nedávné době ve Spojených státech ustavený Projekt lidského genomu (HGP), a pronikání informací o těchto výzkumech do populárních diskursů požaduje znovuprozkoumání současných modelů věd o člověku či biologie. Tento nárůst snahy o zmapování lidské DNA je zároveň projevem moderní formy správy tělesnosti, vyjadřující racionalizační étos možnosti co nejpodrobnější analýzy lidských těl. Vzhledem k ohlášenému výsledku výzkumu lidského genomu (lidé jsou ve svém genetickém ustavení naprosto stejní) je však zajímavé především to, že současné zkoumání HGP se zaměřuje na identifikaci méně než 0,01 \% části DNA, která jednotlivé individuální DNA naopak odlišuje a identifikuje rozdílnosti mezi lidmi. Zaměření se na genetické variace lidského genomu vedlo k výzkumu jednoduchého nukleotidového polymorfismu (SNP), předpokládaného základu pro rozdíly fenotypu, tzn. rozdílu vnějších tělesných znaků: barvy kůže, tvaru očí, typu vlasů apod. Z hlediska sociálních věd a interpretací, které mohou tyto vědy v dané souvislosti nabídnout, patři k zajímavým faktům vytyčení cílů výzkumů genofondu. Ty spočívají právě v popisu genetických diferencí mezi skupinami, které jsou ale zpětně identifikovány podle starých „rasových“ či etnických kategorií, jež se konstruují právě prostřednictvím poukazů na rozdílnosti fenotypu. Takto utvořené rozdílnosti, rétorika spojená s genomem a vědecké informace popularizované veřejným diskursem masových médií navíc mohou v určitých kontextech podporovat i legitimizaci nároku na území obývané určitým etnikem.

Zallúa pak hledal, jak by věda mohla pomoci uzdravit jeho zemi zpustošenou patnácti lety občanské války mezi jejími mnoha náboženskými frakcemi. Zallúa zvlášt' chtěl porozumět genetickým vztahům mezi moderními Libanonci a jejich fénickými předky. Během zdlouhavé krvavé občanské války v 70. a 80. letech minulého století používaly určité skupiny názvu Féničan jako ideologické zbraně. Někteří maronité, převládající křest’anský směr v Libanonu, tvrdili, že pocházejí přímo od Féničanů, aby tak dali najevo, že mají oprávněnější historický nárok na Libanon než pozdější přistěhovalci z Arabského poloostrova. To následně popudilo mnoho muslimů a ze slova Féničan se stalo jiné označení pro křest’ana na rozdíl od muslima. [...] Mohla by genetika ukázat, že moderní Libanonci, křest'ané i muslimové, sdílejí stejné fénické dědictví? To je jedna z otázek, jež tento projekt, financovaný National Geographic Society, doufá vyřešit.

(R. Gore, „Kdo byli Féničané“, $N G$, ř́ijen 2004: 43)

Ukázka referující o výzkumu genetika Zallúy se snaží poukázat na emancipativní charakter prezentovaného výzkumu. Nicméně pohled na sociální konsekvence populárního zpracování tohoto typu výzkumů může ukázat problémy, které v této souvislosti mohou získávat na důležitosti. Zde se mimo jiné vynořují následující otázky: Jak reprezentace současného 
rozvoje genomiky ustavují diference mezi lidmi? Jak jsou v souvislosti s ideou rozdílů mezi lidmi, popř́padě s ideou „rasy“ formulovány koncepty občanství a národní identity? ${ }^{3}$ Text „Kdo byli Féničané“ tak v tomto duchu využívá vyprávění o rozdílnosti a podobnosti etnických skupin pomocí odkazů ke genetické analýze genomu námořníků. Další podobný př́klad spojení metafory krve, analýzy DNA a národnostní přináležitosti je možno sledovat na př́kladu z Islandu, který popisují Pálsson a Rabinow. Tito autoři uvádějí, že pokud na Islandu jedinec daruje krev, tento dar je často použit přímo pro účely genetického výzkumu partikulární nemoci nebo pro léčebnou a zdravotní péči, což má bezpochyby svưj veliký význam. Avšak Pálsson a Rabinow argumentují, že extrakt DNA z krve má také potenciální implikace pro konstrukci nacionality a ohraničení, vymezení občanství. Různé instituce na Islandu sbírají a zaznamenávají DNA odvozené z krevních odběrů a kombinují tak informace založené na krvi s informacemi o rodinném původu. Tato činnost ovšem, jak jsou výše zmínění vědci přesvědčeni, z velké části implicitně podtrhuje pojetí etnické čistoty a národnostní přináležitosti. Jak souvisí sběr DNA vzorků nemocných osob se shromažd’ováním informací o občanech islandského národa? Shromažd’ování vzorků má potenciální implikace pro konstrukci kategorie nacionality, je potenciální demarkační čárou občanství. A tak tato snaha může podle Rabinowa a Pálssona zároveň reprodukovat myšlenku etnické čistoty a přináležitosti k národu (viz Pálsson a Rabinow 2004).

V souvislosti s předchozími př́klady mohou texty odvolávající se na genomický výzkum, který má mít důsledky pro identifikaci určitých etnických skupin, at’ už jde třeba o skupinu definovanovanou např́ílad jako ,potomci Féničanư“, sloužit také jako ilustrace ospravedlňování zahájení (či ukončení) boje proti out-group nebo oprávněnosti sdílení solidarity se „stejnou“" skupinou vykazující společný původ.

Lidé žijící dnes podél pobřeží, kde by bylo nastalo křížení s mořskými národy, mají velmi podobné modely chromozomů $\mathrm{Y}$ jako lidé žijící ve vnitrozemí. V podstatě jsou všichni jeden lid.“ Zallúu takový výsledek potěšil. Podporuje jeho přesvědčení, že libanonští muslimové i křest’ané sdílejí dávné genetické dědictví. „Ted’ bychom snad mohli konečně pohřbít některé z našich vnitřních bojü,“ dodává s nadějí v hlase.

(R. Gore, „Kdo byli Féničané“, $N G$, řijen 2004: 54)

Prostřednictvím populárních reprezentací těl a jejich genomů se kulturně konstruované představy stávají zdánlivě fixními objekty. Jejich „přirozenost“ je tak vytvářena různými výpověd’mi o etnicitě. Za účelem legitimizace partikulárních politických, sociálních a ekonomických programů mohou být potom mobilizovány jisté představy rizika a nebezpečí, které hrozí např́klad národu, národní kultuře a národnímu pokroku. Racionalizace krizí mohou být soustředěny i na rizika ohrožující zdraví (viz Lupton 1999). Riziko a nebezpečí je sociální konstrukcí, která lidi mobilizuje k podpoře a obraně politické a morální pozice a k definování a podpoře hranic mezi Já (self) a ostatními. Nebezpečí a riziko jsou také diskursivní plány, užívané ke konstrukci některých politických a morálních pozic jako přirozených, odvolávajících se na „zdravý rozum“ a na autoritu racionality a ostatních opozičních pozic jako iracionálních a neloajálních. Nárok na podpoření či potlačení rizika či boje mezi různými etnicizovanými skupinami je možné uplatňovat i prostřednictvím jistých kulturních reprezentací tělesnosti. Těla je potom možné analyzovat jako objekty popsané mimo jiné prostřednictvím 
metafory informačního kódu DNA; jsou diskursivními objekty, prostřednictvím kterých je zobrazována a legitimována domnělá přirozenost, autenticita či normalita jistého ustavení sociálních vztahů v prostoru a čase - a tedy i exkluze, odlišení hranic mezi „my“ a „oni“.

V tomto duchu jsou zde tělo a informace DNA určitými kulturními texty, reflektujícími a dávajícími materiální výraz/formu symbolickým hodnotám specifické kultury. Kategorie prírody a kultury jsou v této interpretaci vymístěny ze svých obvyklých lokalizací: nejsou rozděleny podle linií fyzického těla na jedné straně a společnosti na straně druhé. Sociální antropoložka Mary Douglas říká, že co je „přirozené“ (čímž míní to, co je univerzálně sledovatelné naprííc kulturami), není fyzicko-biologické tělo jako takové, ale spíše jistý princip korespondence mezi dvěma těly, fyzicko-biologickým nebo individuálním a sociálním tělem. Tělo je prírozeným symbolem $\mathrm{v}$ tom, že je schopno univerzálně vyjádřit vztah částí nebo individuí $\mathrm{k}$ celku nebo společnosti. Sociální tělo potom omezuje způsob, jakým je vnímáno tělo fyzické (viz Douglas 1969).

To, co je ale v této souvislosti neméně zajímavé, je způsob, jakým se v National Geographic manipuluje s odkazy na tělo jako na součást př́rody, jako na sféru přirozenosti a autentičnosti existence zástupců jistých typů kultur (viz obrázek 1. a 2.). To, co tento typ reprezentace ilustruje, je fakt nikdy neukončeného vyjednávání pozic mezi př́rodou a kulturou, kde je tělo symbolickým, ale stejně tak značně materiálním prostorem; prostorem vytváření hranic mezi prrírodním a kulturním. ${ }^{4}$ Obrázky 1. a 2. ukazují reprezentace těl, která jsou „přirozenými“ objekty, díky tomu, že jsou vizualizovaná jako nahá. To nás přivádí k otázce, jak jsou těla námořníkủ, jejichž DNA a etnický původ jsou podrobeny analýze, vizuálně prezentována.

\section{Je fénická DNA vidět?}

V článku z National Geographic jsou reprezentace sdílené rodinné historie také určitým způsobem vizualizovány, jsou př́tomny nejen prostřednictvím textu, ale i pomocí fotografí́. Na textech National Geographic je obecně zajímavé spojení vizuální a textové reprezentace etnicizovaných těl. Následující prííklad (viz obrázek č. 1) dokládá, jak může specifická forma diskursivního vytváření těl - tedy fotografie ${ }^{5}$ - produkovat představy o jistých typech lidí, tzn. jak jsou prostřednictvím vizuální reprezentace těl vytvářeny taxonomie lidských bytostí a normalizované typy nositelů sociálních identit (viz Edwards 2003).

Uvedený snímek nám umožňuje sledovat, jak spojení fotografie (vizuálního zachycení skutečnosti) a věd o člověku - tedy především antropologie - sleduje diskursivní logiku výpovědi o normalitě nacionalizované core-group nebo, na druhé straně, exotice, deviaci či lidské přirozenosti. Toto spojení se může zdát o to významnější, že připomíná rané dějiny fotografie i antropologie, které byly ovlivněny společenským kontextem vzmáhajících se nacionálních států, kolonialismu a důrazu na vědeckost popisu světa.

Skrze tělo a jeho vizuální reprezentaci je tedy „fénická“ core-group prostřednictvím mimetického zobrazení a spojení se slovy jako např́íklad „původ“, „krev předků“, „tajemství krve“ normalizována a vědění o normálním je potom produktem těchto reprezentací. Zajímavé je zde sledovat postupy, které vedou k produkci takovéto antropologické informace a které jsou předpokladem procesů naturalizace. Fotografie hraje v těchto diskursivních formách, a to nejen $\mathrm{v}$ antropologii, ale také v obecné sféře společenské legitimace a stvrzování pravdy, centrální roli. 
Tyto mechanismy jsou situovány ve foucaultovských kategoriích dohledu, moci a panství, v nichž slouží antropologická fotografie jako médium instrumentální moci.

Moderní západní ideje př́rody, ze kterých National Geographic vychází, vykazují totiž znaky větši přizpůsobivosti při vytváření hranic mezi př́rodou a kulturou, touto velkou bipolární narací, než se obecně předpokládá. To z toho důvodu, že dělicí linie mezi „př́írodou“ a „kulturou“ není v žádném př́ípadě jednoznačná; naopak, je předmětem mnoha vyjednávání a strategické manipulace (viz Wade 2002). Právě v tomto smyslu neexistuje nic takového jako jediný, autentický „,význam přírody“. Př́roda je prríkladem definice kvality, kterou se stává skrze reálné užívání, a je založena na konkrétních sociálně historických kontextech, popisech světa (viz Franklin, Lury a Stacey 2000). Texty v National Geographic, jako ten o Féničanech, jsou také ilustrací symbolické moci využívající konceptu těla jako

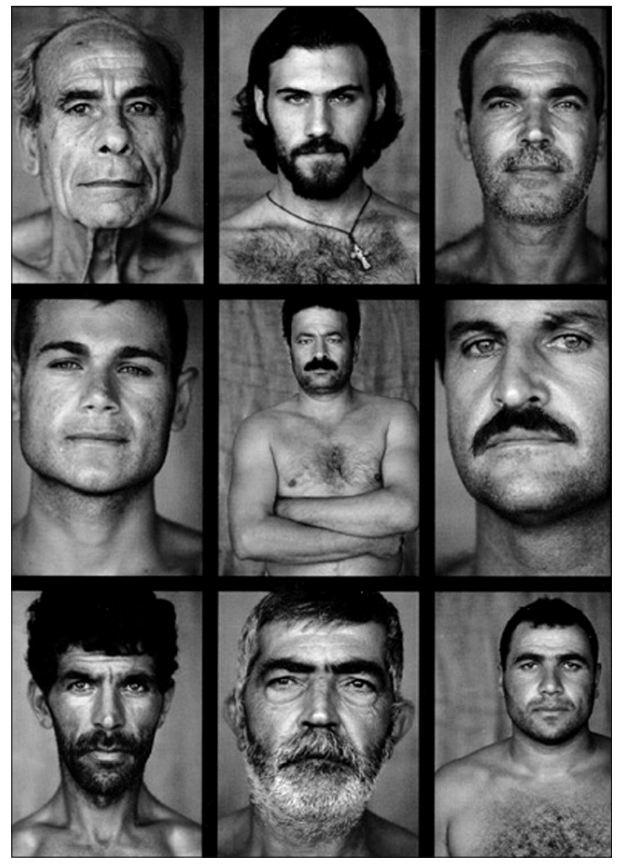

Obrázek č. 1 součásti ideje př́rody či obecnější kategorie přirozenosti. Tato přitom není v pozici statického konceptu, ale ani flexibilního znaku. Těla námořníků jsou prezentována jako polonahá, tedy jako maximálně autentická či přirozená, a zároveň jako objekty umožňující sofistikovaný výzkum, jako objekty reprezentující etnicizovanou kulturu (viz obrázek 1 a 2).

A protože právě tělo a tělesnost jsou základními symbolickými prostory pro konstrukci hranic mezi prŕrodou a kulturou, neboli jsou „přirozenými“ sociálními identifikacemi, je hlavní otázkou to, jak funguje tělo: jako objekt či jako symbol formování core-group a solidarity sdílené v jejím rámci? Tělo a jeho vlastnosti jsou obecně prostorem, mapou, prostřednictvím které je vytvářen symbolický řád (viz Douglas 1996). Je zajímavé, jakým způsobem se v National Geographic zobrazují těla (viz obr. 1 a 2) jako určitý typ esencializace tělesnosti odkazující k ideji přirozenosti sociálních kategorií etnicizované kultury, do kterých jsou zasazena. Způsob vizualizace a popisu těl námořníků v sobě obsahuje také poselství emotivní solidarity se společností, s komunitou, která je $\mathrm{v}$ tomto př́padě soustředěna kolem mytologie krve a původu. To dokládá úryvek z textu o Féničanech, kde novináŕ Rick Gore v intencích popularizace vědy píše o výzkumu dvou vědců - Wellse a Zallúy:

Wells a Zallúa hledají genetické znaky, mutace vzniklé ve fénických dobách, které lze i dnes ještě v krvi nalézt [...]. „Jsem Féničan, “ ̌ríká mladý muž a uvádí tak jméno národa, který zmizel ze scény světových dějin před dvěma tisíci let. „Přinejmenším se cítím jako jeden z nich. Moji př́ibuzní zde po staletí byli rybáři a námořníky.“ [...] Wells ani trochu nepochybuje o účinnosti nových genetických technik, jichž používá k lepšímu poznání starých, dnes i někdy dávno zaniklých národů.

(R. Gore, „Kdo byli Féničané“, $N G$, ř́ijen 2004: 43) 


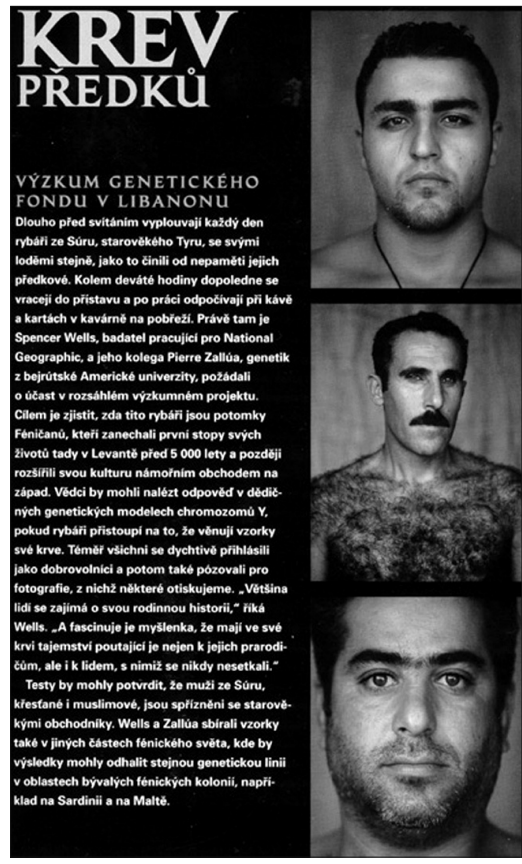

Obrázek č. 2
Idea přirozenosti komunity je zde vyjádřena pomocí symboliky přirozenosti těl. Je demonstrována skrze symboly, které jsou samy o sobě konstrukcí danou na základě zkušenosti, tzn. neuvědomělé zkušenosti, která je tudíž kvasipřírodní. Příroda a tělesnost jsou ovšem umělými, konvenčními produkty, tudíž opakem toho, jak obvykle chápeme koncept „prrirozeného“. Takovýto proces kulturalizace přirozených zobrazení těl a jejich popis využívající mytologie krve či původu produkuje také identity a mezilidské vztahy. Avšak spíše než aby byl překrývající vrstvou či opozicí př́rody, vyjednává prostor mezi hranicemi prírodního a kulturního pole. Což znamená, že „příroda“ může namísto fixní představy přirozené entity zaujmout pozici kulturního konceptu, právě tak jako se může „kultura“ stát přirozenou. Toto narušení zdánlivě pevných obrysů mezi „př́ŕodou“ a „kulturou“ má důsledky pro způsob, jakým rozumíme ideám a praktikám týkajícím se např́klad identifikačních kategorií etnicity či „rasy“ (viz Wade 2002).

\section{Nacionální biomoc/biopolitika}

Zde se dostáváme $\mathrm{k}$ nejdůležitější části mé argumentace analyzovaného problému, tedy $\mathrm{k}$ tomu, jak se popularizace výzkumů DNA mohou stát konstitutivní složkou výpovědí o souboru primordiálních charakteristik core-group konkrétního etnika či národa. V předchozí části textu jsem na př́kladu úryvků z textu „Kdo byli Féničané?“ ukázala, jakým způsobem jsou reprezentována těla skupiny libanonských námořníků ve spojení s výzkumem jejich DNA a kategorií etnické př́ślušnosti. Jakou funkci však mají tyto kulturní reprezentace DNA či projektů mapujících genom, jimiž se zabývají texty v National Geographic? Je způsob informace o zmapování genomu něčím specifický z hlediska nároku na legitimitu etnické, nacionální identifikace? Následující část textu zaměřuje pozornost na způsob tvorby a reprezentace těl, který odkazuje ke strategii modernity odvíjející se z přesvědčení o možnosti vědeckého a racionálního zmapování lidského těla jako entity oddělené od ratia. Všímám si tedy role, jakou hrají v konstituci moderní národní komunity odkazy ke „genom projektům“ jako projektům popisujícím a klasifikujícím národní populace. Zároveň se zajímám o to, jak tyto reprezentace individualizují subjekty v jejich tělech a vypovídají o jejich partikulární formě lidství, at' už etnické, „rasové“ apod. DNA je zde zdrojem informací, reprezentací moderní technologie správy života, těl tvořících národní, etnicizované populace. Podrobněji se pak zaměřuji na otázky moderní formy správy a administrace lidských těl, jichž je analýza DNA nedílnou součástí.

Teoretické uchopení uvedené problematiky mi umožňují díla Michela Foucaulta či Paula Rabinowa, která se zabývají podmínkami diskursivního utváření sociálního těla. Zajímá mne 
především jejich analýza současných forem konceptu biomoci, jež mají podobu genetizace těla. Dalším relevantním tématem zastoupeným v jejich dílech je zkoumání kulturních důsledků výzkumu DNA a oblasti produkce pravdy o životě ve světě ovlivňovaném biotechnologiemi a utváření souvislosti mezi lidským genomem a nacionální přináležitostí. Paul Rabinow spolu s Nicolasem Rosem analyzují kategorii života a biomoci v současných pozdně moderních podmínkách a rámují tuto oblast třemi tématy, kterými jsou: „rasa“, reprodukce a genetika (viz Rabinow a Rose 2003). A právě koncepty či výkladové rámce biopolitiky či moderního typu administrace nacionalizovaných a etnicizovaných společností se dají použít při analýze populárních reprezentací a reprodukcí výzkumů DNA.

Biomoc jako zásadní moderní technologie správy, at’ již individuí či celých populací, je charakterizována vstupem života a jeho mechanismů do sféry vzájemného působení moci a vědění, života, který byl vložen do politiky. Těla a jejich zrod se tak stávají diskursivními objekty, prostřednictvím kterých je možno sledovat způsoby „vtělení“ moci a vědění v (pozdně) moderní společnosti. $\mathrm{V}$ průběhu dějin se tato moc rozvíjela ve dvou vzájemně propojených oblastech: první z nich se při svém formování soustředila na tělo jako stroj, na zvyšování a zdokonalování jeho schopností, na růst jeho užitečnosti a poslušnosti, na jeho zakomponování do sfér administrativní správy a ekonomické kontroly: to vše vytvářely formy moci, které Michel Foucault nazývá disciplinami anatomo-politiky lidského těla. Druhá forma moci nad životem, která se zformovala asi v polovině 18 . století, se soustředila na tělo-prostor, na mechaniku živého a na to, co je v základu biologických procesů: plodnost, porodnost, úmrtnost, zdravotní stav apod. Kontrola nad nimi je dána nepřeberným množstvím intervencí a rozličných způsobů regulativních kontrol; Foucault je označuje jako biopolitiku populace. ${ }^{6}$

V knize Vủle k vědèní (1999) pak Michel Foucault znovu uvedl a identifikoval tuto specifickou formu moderní administrace života ve společnosti, formu moci, která činí lidský život a jeho projevy viditelnými a zároveň umožňuje racionální vytváření a disciplinaci tohoto života. Nejedná se přitom, ve srovnání s tradiční pater potestas, o nahodilou moc nad životem a smrtí, ale o prenos personifikované pastorální moci panovníka na stát, na produktivní a racionální vytváření a správu lidských životů, těl, populací. Na poli tělesnosti je potom prostřednictvím součinnosti moci a vědění utvořena hranice mezi tím, co má žít a co musí zemřít. Přičemž smrt zde není „pouze“ smrtí fyzickou, biopolitické postupy mohou život redukovat sociálně: tato smrt může být společensky artikulována i jako vyhnání, odsun, zničení, uzavření do ghett, věznic, či ustanovení speciálních statusů pro určité skupiny obyvatel, kterým je umožněno koexistovat ve společnosti, ale jež jsou připraveny o specifická práva či o podíl na sociálních aktivitách, jako je např́iklad volební právo pro ženy, občanství druhé kategorie apod. (viz Lemke in Stingelin 2003).

V současné době se, v důsledku rozvoje tak rozdílných sfér jako jsou biologická reprodukce, projekt lidského genomu, plastická chirurgie či věda o sportu, stávají lidské tělo a tělesnost stále více fenoménem volby a výběru či př́ležitostí (viz Shilling 2000). To souvisí s nejistotou týkající se toho, jak se má zacházet s reprezentacemi hranic mezi „prírodou“ a „kulturou“, „správným“ a „nesprávným“ “životem. Charakteristickým rysem současnosti je naše ambivalentní setkávání se $\mathrm{s}$ biotechnologiemi, které jde ruku v ruce s procesem kulturní redefinice porozumění lidství, tělu, reprodukci. Ovce Dolly, analýzy DNA, exkluze určitých těl apod. jsou příklady, jež nás odkazují k širší foucaultovské otázce, jak můžeme výše zmíněným záležitostem rozumět jako součástem současné nacionální biopolitické governmentality.? 
Tento text za mnohé vděčí inspiraci, kterou v sobě obsahují texty Michela Foucaulta, autora, jenž uvedl do sociální a kulturní teorie téma diskursivního utváření „Člověka“ a jenž zdůraznil roli, jakou v této perspektivě hrají kategorie života, tělesnosti, či podrobněji koncept biomoci/biopolitiky, neboli správy národní populace. Michel Foucault identifikuje tři diskursy, v rámci kterých se na sklonku klasické doby konstituuje objekt zvaný „Člověk“ (l’homme). Člověk se podle něj objevuje v průniku tří domén: života ${ }^{8}$, práce a jazyka, v jejichž rámci se neustále a nestále sjednocuje a konstituuje jako suverénní Subjekt (viz Rabinow 2003a). Pojem biomoc odkazuje ke správě moderních těl a dává výraz jistým novým sociálním zkušenostem a fenoménům. Je spojován mimo jiné s termíny, jako jsou např́íklad biotechnologie, výzkum kmenových buněk, DNA, klonování, vývoj v oblasti reprodukčních technik apod. (viz Stingelin 2003). Namísto dřívějších sociobiologických projektů sociálně inženýrského sadismu a ovlivňování, at' již je to projekt nacionálního socialismu či eugenické projekty americké, anglické či francouzské provenience, přichází na pořad dne tzv. biosocialita (viz Rabinow 2003b, Wade 2004), opřená o dva hlavní argumenty: moc je vtělená a vzájemné působení moci a vědění, které vytváří specifické sociální „reálie“, je „vtěleno“. Například koncept přírody, ve smyslu přírodních faktů, jako je „fakt lidského života“, byl v moderní době biologizován tak, že kupř́íkladu začátek života byl reprezentován jako evoluční narativum př́rodního výběru. Při odkazování k přírodním faktům lidské různosti, faktu života, evoluci homo sapiens, se jedním z diskursivních rámců interpretace lidství stala biologie, která je v současnosti geneticizována (viz Franklin, Lury a Stacey 2000).

Navzdory faktorům, které podporují rozvoj biopolitiky i panoptikální kontroly těla a tělesnosti, se v rámci diskursu popularizace vědy objevují paradoxní situace. Existuje řada možností, jak vynaložit úsilí na maximální kontrolu nad těly a věděním o nich. Zároveň však žijeme ve věku, který je charakterizován radikálním zpochybněním našeho vědění o tom, co „národní těla“ jsou a jak jsou regulována a kontrolována (viz Shilling 2000). Vývoj biotechnologií nejenže rozšiřuje pole dosud známých možností jednání, nýbrž umožňuje i nový typ státních či expertních zásahů a regulace - tedy nové formy biopolitiky. To, co bylo dosud „dáno“, čili vnímáno jako organická přirozenost, co mohlo být nanejvýš pouze „šlechtěno“, se nyní posouvá do oblasti cílených zákroků. Stírá se hranice mezi přirozeností, kterou ,jsme“, a organickým vybavením, které si sami „utváríme“ (viz Habermas 2003).

Paul Rabinow píše ve svých pracích o nových formách biopolitiky v souvislosti s ,purifikací“ nacionality. V tomto kontextu je DNA chápána ne jako biologická entita, ale jako specifický druh informace a výzkum spojený s genomikou a DNA je pojímán jako „kulturní kód“" kategorie lidství (viz Rabinow 2004). K tělesnosti se zde přistupuje jako k předmětu i prostředku sociální distribuce vědění, a to konkrétně vědění o symbolických hranicích lidství, čili jako k součásti symbolického světa. ${ }^{9}$ Jakou perspektivu nám nabízí uvedený koncept moderní biomoci, správy nacionálních těl, jejichž nedílnou součástí je právě analýza DNA? Poukazuje mimo jiné i na to, jakým způsobem mohou být „národní těla“ spravována. A to nejen na úrovni reprezentací, což jsem ilustrovala v první části svého textu, ale i na úrovni administrativní správy a jednání či konkrétních politických ovlivňování biopolitické govermentality při vytváření tzv. populačních optim, sledování „kvality“ zdraví národní populace apod. 


\section{Závěr}

V předchozím textu jsem se věnovala poměrně nové oblasti sociálně vědné analýzy, která se zabývá tématem popularizace genetického výzkumu a vyjednáváním hranic mezi prírodou a kulturou. A v této souvislosti také rolí kulturních reprezentací těl. Tato oblast mého zájmu se dotýká zejména podmínek identifikace sociálních skupin definovaných pomocí kategorií etnicity v souvislosti s popularizací DNA výzkumu. Zde jsem si všimla výpovědí o způsobu etnické identifikace ve spojení se specifickým typem kulturní reprezentace tělesnosti. Prostřednictvím ukázek z textu „Kdo byli Féničané“ z National Geographic a na základě sledování reprezentací těla, které přinášejí popularizace př́rodních věd, jsem z hlediska sociální a kulturní teorie nezkoumala ontologickou povahu DNA kódu nebo funkci jednotlivých genů, protože tento typ zkoumání postrádá z hlediska sociálně konstruktivistické teorie prostupnosti hranic mezi koncepty prírody a kultury smysl, ale analyzovala jsem fenomén mapování lidské DNA a jeho reprezentace, které mají řadu sociálních a kulturních konsekvencí. Stejně tak předchozí text neupírá legitimitu výzkumům genetiky v oblasti zdravotní prevence, nicméně poukazuje na důležitost analýzy diskursivních výpovědí týkajících se spojení výzkumů DNA a nacionální identifikace vzorků, které s sebou tyto databáze vytvářené pro účely zdravotní prevence nesou. Neboli poukazuje na možné důsledky vědeckého výzkumu pro politizaci správy těchto vzorků či politiku populárních reprezentací výzkumů. Podobně jsem v př́padě interpretace výroků odkazujících ke krvi předků nehledala pravdu o rozdílném složení krve určitých sociálních skupin, ale snažila jsem se popsat předpoklady a konsekvence rétoriky, která obsahuje metafory krve a mytologie původu jako symbolů, které využívá k vytváření či zdůraznění komplementarity shodnosti a rozdílů mezi jednotlivými lidmi či skupinami.

Ukázala jsem, jak se odkazy na tělesné diference či shodnosti stávají součástmi kulturních distinkcí; kolem zdánlivě „přirozených“ kategorií genů, původu či krve se vytváří kulturní narativa stejnosti či diference. Určité distinktivní vlastnosti (jako např́íklad bílá nebo černá barva kůže, štíhlost nebo tloušt’ka) se přitom mohou stát viditelným, ne-indiferentním a společensky zřetelným rozdílem jedině tehdy, jsou-li vnímány a popisovány někým, kdo je schopný tyto vlastnosti rozlišit. Tedy tím, kdo neproblematizuje takovýto způsob rozlišování. Existence jisté vlastnosti jako vlastnosti distinktivní tak předpokládá subjekt a typ čtenáře, který je zapojen do daného sociálního prostoru a jistého typu sociální výpovědi. Takovýto čtenář není indiferentní a vládne kategoriemi vnímání, klasifikačními schématy, které vytvářejí a umožňují uvedené rozlišování. Tato diference navíc existuje pouze jako vztahová vlastnost, jako možné umístění v sociálním prostoru (viz Bourdieu 1998).

A právě současné formy distinkcí, definování rozdílů mezi lidmi či např́iklad ideje „rasy“ a nacionální purifikace inkorporují nové obsahy a nové formy. To je možné sledovat například v rozvoji již zmíněných národních genomických projektů. Přesto nejde v předcházejícím textu o reflexi toho, co by se dalo nazvat genetickým neorasismem, ale o analýzu reprezentací genetizovaného těla jako symbolické hranice v utváření a naturalizaci stejnosti a diference. A také o poukaz na to, jak jsou individua $\mathrm{v}$ prostředí biosociality prostřednictvím analýzy DNA lokalizována podle zvýznamněných tělesných znaků. To znamená, že individuální aktéři jsou seskupeni do (např́klad) etnicky definovaných skupin, a to způsobem, který je nejen dekontextualizuje vzhledem k jejich sociálnímu prostředí, ale zároveň z nich utváŕí do určité míry ne-subjekty: nebot' přiřazování do skupin následující objektivizující hlediska již neodpovídá subjektu v obvyklém moderním slova smyslu, subjektu jako jednotě sociální, historické a tě- 
lesné zkušenosti. Objektivismus sociálních faktorů je potom vystř́dán genetikou, prostřednictvím které dochází k novému ustanovování a operacionalizaci konceptu př́rody a přirozeného za vzniku možnosti nové tvorby etnicizovaných sociálních identit (viz Rabinow 2003b).

Sociální reprezentace kategorie těla a života a jejich využití v praxi následně vytvářejí celý aparát dohlížející společnosti, legitimující se např́íklad prostřednictvím definic rizikových skupin, př́padně geneticky, v odkazech na „původ“ určitých skupin. Nemám zde přitom na mysli populární vědění o triviálním sobeckém, altruistickém genu či genu alkoholismu. Mou snahou je ukázat, že pomocí vědění, moci a technologie se popisuje a vynalézá prríroda, jež je v důsledku zmíněných praktik neustále kulturně formována. Kultura se $\mathrm{v}$ důsledku tohoto procesu stává přirozenou a př́roda kulturalizovanou (viz Rabinow 2003a). To, co je či není považováno za přirozenou sféru těla či tělesnosti, je reprezentací sociálních procesů, souhry moci a vědění. Reprezentace těl ovšem umožňují určité představy rizika, vytvářejí hranice mezi morálním či nemorálním, přijatelným či neprijatelným, přirozeným či nepřirozeným. Vědění a technologie jednak strukturují tělo fyzické, jednak prostřednictvím imaginace DNA, nemoci, zdraví, „rasy“, legitimují nerovnost, př́islušnost ke kolektivitě apod. Prostřednictvím biosociality, jsou v pohybu procesy neustálého přepisování hranic mezi př́rodou a kulturou. Ve srovnání s revolucí, $\mathrm{k}$ níž došlo ve fyzice, skrývají reprezentace výzkumů genomu pravděpodobně větši potenciál $\mathrm{k}$ přetvoření společnosti a života, zde popisované na mikrorovině řady popularizací, biopolitických praktik a diskursů. Populární reprodukce a recyklace výzkumů DNA, a zde zejména již zmiňovaných variací jednoduchých nukleotidů navázaných na staré fenotypové kategorie, s sebou ovšem nesou nejen velké př́sliby, ale i nebezpečí.

\section{Poznámky}

1 Může ale výzkum DNA ukázat, že dvě rozdílné etnické skupiny mají identické variace genotypu nebo naopak, že v rámci jedné etnické skupiny lze pozorovat různé genotypové variace? Tato otázka nás přivádí $\mathrm{k}$ tomu, že reprezentace výzkumu DNA nemusí nutně odkazovat $\mathrm{k}$ jednoznačné identifikaci dvou etnických skupin jako genotypově rozdílných a nemusí nutně sledovat myšlenku potvrzení již konstruovaných sociálních skupin z hlediska jejich etnicity. Sociálně konstruovaný popis genotypu se tedy nemusí nutně krýt s identifikací etnickou. Co je ale zajímavé a hodno pozornosti je to, že v diskursu popularizace př́rodní vědy, tedy v našem př́ípadě v National Geographic, je reprezentovaná možnost spojení mezi identifikací etnického původu a genotypem, tzn. neproblematičnost spojení mezi identifikací původu etnické různosti či stejnosti lidských bytostí a jejich biologickými vlastnostmi. Jinou otázkou zůstává, „co s tím?“, neboli jaké mají tyto reprezentace sociální konsekvence. Netvrdím, že vždy negativní a ideologické, to samozřejmě závisí na kontextech, v jejichž rámci je konkrétní výzkum realizován, popř́ípadě interpretován.

2 Koncept homogenity ,jádra“ národa či etnika je analytickým nástrojem, prostřednictvím kterého může kritická teorie poukázat mimo jiné právě i na problematičnost představ o tzv. typických Libanoncích, ale obecně i o jiných etnicizovaných skupinách, a na neadekvátnosti jejich charakterizace na základě tělesných vlastností.

3 Idea „rasy“ je mimo jiné i otázkou symbolizace těla, např́íklad právě zvýznamněných geneticky definovaných tělesných znaků - barvy kůže či fenotypu jako „přirozených, evidentních“ charakteristik. To znamená, barvy kůže či složení genů jako médií toho, co by mohlo být nazýváno druhou př́rodou nebo kulturním esencialismem. Symboly barvy či genů zde fungují jako média diference. „Rasa“ potom není „reálnou“: není založena na biologii, ale má svůj původ v kultuře, kde kultura je chápána jako druhá prŕroda. Biologie tak již není v př́rodních ani sociálních vědách referentem „rasy“, ale je to „rasa“, co je utvářeno pomocí barev a metafor genů konstituovaných v arbitrárních 
vztazích mezi označujícím a označovaným. Kultura je zde chápána jako fixní zdroj identity; je stvrzována způsoby, které reprodukují naturalizované hierarchie etnicizovaného občanství v prostředí mezi-národní migrace (viz Lury, Franklin a Stacey 2000).

Moderní strategie symbolizace těla je i součástí širšího nároku na pevnost „dané“ hranice mezi prrírodou a kulturou. Konstruování těchto hranic není popisem již existujících rozdílů, ale procesem neustálé purifikace, očišt’ováním od hybridních stavů, lidí, objektů, procesem snahy o dosažení „autentického“, „prrirozeného“" stavu (viz Latour 2003).

5 Pokud se díváme na věc z hlediska propojení fotografie a antropologie ve věci vizualizace „Druhého“, v pozdním 19. století existoval v rámci přírodních věd vzrůstající trend k replikaci, k reprodukci př́rodních fenoménů v celé jejich komplexitě v laboratoři. Mimetická tradice byla dílem neustálých dialogů mezi obecnou teorií a prezentacemi přírodních fenoménů. Použití fotografie jako materiální manifestace rané antropologické taxonomie by mohlo být chápáno jako spojení, prolnutí těchto obou tradic - mimetické a analytické. Nadšení pro mimetické je také obzvláštním poznávacím znamením populární kultury (viz Edwards 2003).

6 Disciplíny těla a regulování populace konstituují dva póly, kolem nichž se rozvíjí moc nad životem. Zavedení této technologie dvou tváří - anatomické a biologické, individualizující a klasifikující, obrácené k projevům těla a zaznamenávající procesy života - během klasického věku charakterizuje moc, jejíž hlavní funkcí již není zabíjet, nýbrž prosazovat krok za krokem život. Starodávná moc smrti, symbol panovníkovy moci, je nyní důsledně zatlačována do pozadí pěstováním kultu těla a racionální správou života. Během klasického věku došlo k rychlému vývoji rozmanitých disciplín - škol, kolejí, kasáren, dílen; objevily se problémy porodnosti, dlouhověkosti, veřejného zdraví, bydlení, migrace na poli praktické politiky a ekonomických pozorování; nastala exploze rozmanitých a početných technik, které mají zajistit podrobení těla a kontrolu populace. Tímto se otevírá éra „biomoci““(viz Foucault 2002).

„....moderní strategie vládnutí je Foucaultem chápána jako strategie reprodukce společností formováním kategorizované a řízené populace $\mathrm{z}$ obyvatel politicky vymezeného teritoria. Tato strategie pracuje pomocí disciplinačních institucí a institucionalizovaných forem vědění, tedy za pomocí diskursů, jako je demografie, statistika, kriminologie, správa, medicína, vzdělání apod. Foucault zdůrazňuje, že tato strategie nestojí v protikladu vůči individualitě lidských bytostí, ale že utváří sebe-reflexivní způsob chování“ (viz Szaló 2004:25).

8 Zde je důležité zmínit i francouzského historika Georgese Canguilhema, jehož esej „Koncept života“ (1966) se zabýval kulturní analýzou, ,života jako produktivní síly“. V analýze genealogie tohoto konceptu od starověku po dnešek Canguilhem zdůrazňuje specifičnost současného rozumění tématu života, jež je v moderní době odvozeno z perspektivy molekulární biologie. Canguilhem zdůrazňuje významnost moderního biologického modelu života, který je založen na tom, že jde o informační model (viz Canguilhem in Lury, Franklin a Stacey 2000).

9 „Symbolický svět přisuzuje v hierarchii bytí nejrůznějším jevům různé stupně a definuje rozsah sociálního světa v rámci této hierarchie. Není tř̌eba zdůrazňovat, že tyto stupně jsou přisuzovány i různým typům lidí a často dochází k tomu, že celé kategorie takových typů (někdy jsou to všichni, kteří stojí mimo dané společenství) jsou definovány jako jiné než lidské či jako méně lidské“ (viz Berger a Luckmann 1999: 103).

\section{Literatura}

Alexander, J. 2003. The Meanings of sSocial Life: a Cultural Sociology. Oxford, New York: Oxford University Press.

Berger, P. a Luckmann, T. 1999. Sociálni konstrukce reality: Pojednání o sociologii vědění. Brno: CDK. 
Bourdieu, P. 1998. Teorie jednání. Praha: Karolinum.

Calsamiglia, P., van Dijk, T. 2004. „Popularization discourse and knowledge about the geonome.“ Discourse and Society, Vol 15(4): 369-389.

Douglas, M. (1970) 1996. Natural Symbols. Exploration in Cosmology. London a New York: Routledge.

Douglas, M. 1969. Purity and Danger: An Analysis of the Concepts of Pollution and Taboo. London: Routledge \& Kegan Paul.

Edwards, E. 2003. „Andere ordnen. Fotografie, Anthropologien and Taxonomie.“ In: Diskurse der Fotografie (Fotokritik am Ende des Fotografischen Zeitalters). Frankfurt am Main: Suhrkamp.

Franklin, S. Lury, C. Stacey, J. 2000. Global Culture. Global Nature. London: SAGE.

Foucault, M. 1999. Déjiny sexuality I. Vưle k vědění. Praha: Hermann \& synové.

Fraser, M., Greco. M. 2004. The Body. A Reader. London: Routledge.

Habermas, J. 2003. Budoucnost lidské přirozenosti: na cestě k liberální eugenice? Praha: Filosofia.

Latour, B. 2003. Nikdy sme neboli moderní: esej o symetrickej antropológii. Bratislava: Kalligram.

Lupton, D. 1999. Risk and Sociocultural Theory: New Directions and Perspectives. Cambridge: Cambridge University Press.

Rabinow, P. 2003a. Anthropos Today. Reflections on Modern Equipment. Princeton: Princeton University Press.

Rabinow, P. 2003b. Antropologie der Vernunft. Studien zu Wissenschaft und Lebensführung. Frankfurt am Main: Suhrkamp Verlag.

Rabinow, P. a Rose, N. 2003. Thoughts On the Concept of Biopower Today. Html dokument dostupný z: http://www.molsci.org/files/Rose_Rabinow_Biopower_Today.pdf

Rabinow, P., Pálsson, G. 2004. „The Icelandic genome debate“. Html dokument dostupný z: http://ls126.molsci.org/files/Rabinow___Icelandic_Genome.doc

Shilling, Ch. 2000. The Body and Social Theory. London: SAGE Publications.

Stingelin, M. 2003. Biopolitik und Rassismus. Frankfurt am Main: Suhrkamp.

Szaló, C., Nosál, I. (eds.) 2003. Mozaika v re-konstrukci: formování sociálních identit v současné středni Evropě. Brno: Mezinárodní politologický ústav.

Wade, P. 2002. Race, Nature and Culture: An Anthropological Approach. London: Pluto Press.

Prameny

Gore, R. 2004. „Kdo byli Féničané.“ National Geografic, ř́́jen: 34-55.

Bruchac, J. 2004 „Indiánské obrození.“ National Geographic, řrijen: 104-122.

Viviant, F. 2005 „Písně Čangů.“ National Geographic, červen: 100-118.

\section{Autorka}

Eva Šlesingerová působí na Katedře sociologie, oboru Sociální antropologie FSS MU v Brně, kde vyučuje předměty Současná sociální a kulturní teorie, Rasismus a idea rasy a další. Zabývá se tématy konstrukce identit, tělesnosti a jejich reprezentacemi v populární kultuře. Kontakt: eslesi@fss.muni.cz 